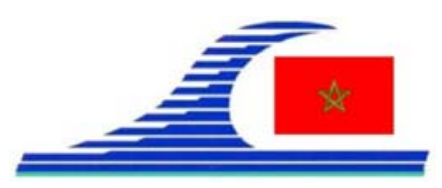

Conférence Méditerranéenne Côtière et Maritime

EDITION 2, TANGER, MAROC (2011)

Coastal and Maritime Mediterranean Conference

Disponible en ligne - http://www.paralia.fr-Available online

\title{
Statistics of wind and wind power over the Mediterranean Sea
}

\author{
Abderrahim BENTAMY ${ }^{1}$, Denis CROIZÉ-FILLON ${ }^{1}$ \\ 1. Laboratoire d'Océanographie Spatiale, IFREMER, France. \\ abderrahim.bentamy@ifremer.fr
}

\begin{abstract}
:
Several national, European, and international projects are currently dealing with the operational productions of marine energy such as current, tidal, waves, thermal, and wind energies. In this study we examine the potential of marine wind, derived from satellite scatterometer observations, to be used for the characterisation of wind power over the Mediterranean Sea. Indeed, only such radars onboard satellites provide valuable information on wind speed and direction with sufficient spatial and temporal sampling under all weather conditions and during days and nights. Twenty years of remotely sensed data retrieved from scatterometers onboard satellites and operating from 1992 trough 2011 are used to estimate the conventional moments and the associated wind distribution parameters. The statistical results are used to investigate the wind power distributions. The latter meet the previous results obtained from numerical models. However, they exhibit higher space and time resolutions and amplitudes.
\end{abstract}

Keywords: Energy - Wind power - Mediterranean Sea

\section{Data}

The scatterometer principle is described in wide scientific papers (see for instance BENTAMY et al., 2011). The scatterometer antennas emit towards surface microwaves, which are scattered by short sea waves (capillary/gravity waves). The latter are strongly related to changes in surface winds. Figure 1 shows scatterometers used in this study. Their operating periods are provided in the figure caption. Surface wind speeds and directions are available over scatterometer swaths with various orbit and spatial resolution characteristics. The ERS 1 and ERS-2 scatterometers are an active microwave instrument that produces wind vectors (wind speed and direction) at $50 \mathrm{~km}$ resolution with a separation of $25 \mathrm{~km}$ across a $500 \mathrm{~km}$ swath. NSCAT onboard ADEOS-1 satellite has two swaths of $600 \mathrm{~km}$ wide, located on each side of the satellite track. NSCAT retrievals used in this study are from baseline products. Surface winds retrieved from SeaWinds scatterometers on board QuikScat and ADEOS-2 are provided at Wind Vector Cells (WVC) over swath of $1800 \mathrm{~km}$ wide. Since 2007, valuable surface winds are retrieved from ASCAT onboard Metop-A over two swaths of $550 \mathrm{~km}$ width. For this study, $25 \mathrm{~km}^{2}$ and $12.5 \mathrm{~km}^{2}$ winds are used for statistic purpose. The accuracies of scatterometer wind speeds and directions were investigated by several authors 
La connaissance de la Mer:

un vecteur du développement durable en Méditerranée

(BENTAMY et al., 2002; BOURASSA et al., 2003; EBUCHI et al., 2002). It was determined through comparison with in-situ wind measurements (buoy and ships). It was found that that the remotely sensed winds compare well with in-situ measurements. For instance the rms differences of wind speed and direction are about $1 \mathrm{~m} / \mathrm{s}$ and $23^{\circ}$, respectively. The correlation coefficient exceeds 0.92. Figure 2 provides an illustration of the accuracy results obtained at Météo-France buoy located in Gulf of Lion.

\section{Wind distributions}

All available and valid remotely sensed wind speeds and directions, derived from scatterometers described above, and occurring the period 1992 trough 2011, are used. Even tough the study deals with all the Mediterranean Sea, only results obtained the western area are illustrated in this paper.
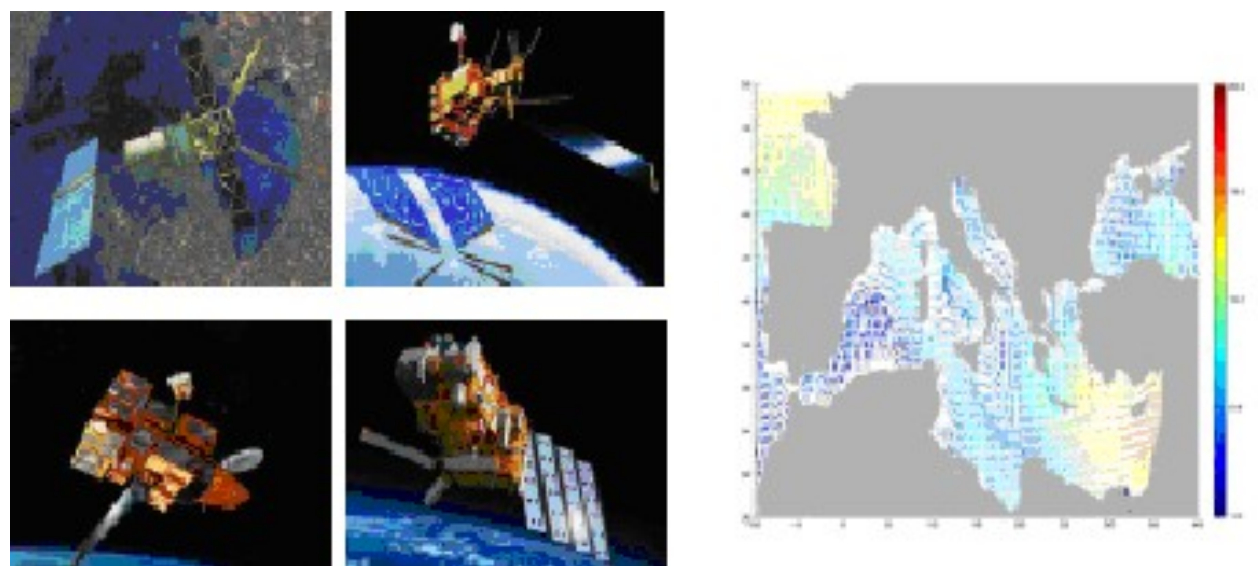

Figure 1. Satellites launched since 1991 carrying on scatterometers: ERS-1 (19911996/top-left); ERS-2 (1995-2001/top-left); NSCAT on board ADEOS-1 (1996-1997/ top-right); Seawinds onboard QuikSCAT (1999-2009/bottom-left); ASCAT on board Metop-A (2007-Present/bottom-right). Left panel indicates an example of surface wind speed (in colour) and direction (arrows) derived from scatterometer measurements.

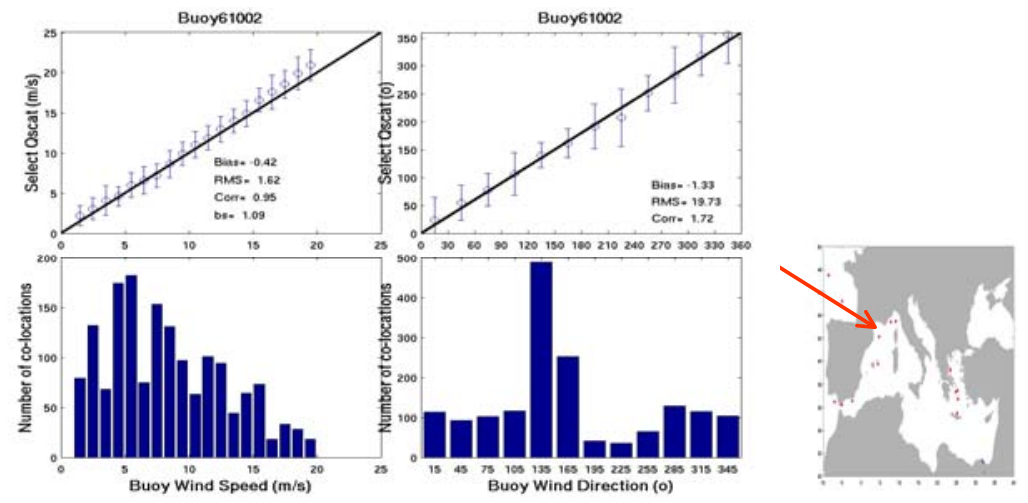

Figure 2. Comparisons of buoy, moored and scatterometer wind speeds (left) and directions. 
More than 23 millions satellite observations are used in this study. Data are available over scatterometer swath and are unevenly distributed spatially. To enhance statistical calculations, retrievals are sorted into $0.10^{\circ}$ longitude and $0.10^{\circ}$ latitude bins. More specifically, all satellite data occurring within $25 \mathrm{~km}$ from $0.10^{\circ} \times 0.10^{\circ}$ grid points are selected. The number of instantaneous satellite retrievals falling within each grid point exceeds 100 and reaches 3823 (figure 3).

\subsection{Distributions of the statistical moments}

The remotely sensed data sets are used to compute the leading two first moments: mean and standard deviation of wind speed and wind components. Both the mean and standard deviation are highly related to sea zone characteristics. The main known surface wind features are clearly depicted. The surface wind vector is characterized by a large spatial and temporal variability. Even though the seasonal signal is quite common to several sub-basins of the Mediterranean Sea, significant regional changes in its amplitude and phase are depicted (BENTAMY et al, 2007).

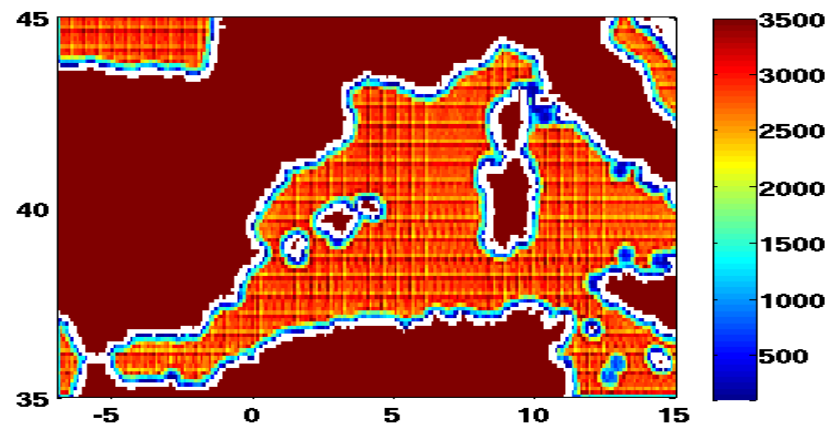

Figure 3. Sampling length spatial distribution: 1992-2001.

Indeed, several local wind conditions exist and might have remotely impact on the global space and time wind patterns. For instance, some large scale wind regimes are clearly identified (figure 4). The Mistral wind blowing into Gulf of Lion from the southern coast of France, and winds blowing in the Alboran Channel and through the Strait of Gibraltar: Westerly and Levante winds (east to northeast) are depicted. These common features are clearly depicted from spatial distributions of means and standard deviations shown in figure 4 . On average, wind speeds varie between $5 \mathrm{~m} / \mathrm{s}$ and $8 \mathrm{~m} / \mathrm{s}$. The highest mean winds are associated with the mistral event, while the lowest are located in eastern area. High wind conditions are also depicted cross Gibraltar strait and at east of North Africa. However, such mean spatial features should be considered carefully. Indeed, the standard deviation patterns indicate that wind vector is highly variable in both space and time. Such variability is highly related to wind seasonal patterns. For instance during winter season (December - January - February), the percentages of low (less than $5 \mathrm{~m} / \mathrm{s}$ ), medium $(7 \mathrm{~m} / \mathrm{s}-9 \mathrm{~m} / \mathrm{s}$ ), and high winds (great 
La connaissance de la Mer:

un vecteur du développement durable en Méditerranée

than $15 \mathrm{~m} / \mathrm{s}$ ) are about $16.23 \%, 18.58 \%$, and $07.20 \%$ respectively. These rates are about 35.93\%, 19.37\%, and 0.59\%, during summer season (June - July - August). Furthermore, the spatial distribution of wind condition frequencies is not uniform over the study region (figure 5). The highest wind conditions (exceeding $10 \mathrm{~m} / \mathrm{s}$ ) are mostly found in Gulf of Lion and at Gibraltar strait. There is a factor 4 between northern and southern regions and highly related to wind characteristics in the Mediterranean sea (BENTAMY et al, 2007). Their occurrences retrieved from remotely sensed data are 2447, 924, 216, and 937 during winter, spring, summer, and fall seasons, respectively.

\subsection{Satellite wind power density}

The remotely sensed wind data are used to estimate the distribution of power density $(E)$ over the Mediterranean sea. The latter is estimated as:

$E=(1 / 2) * \rho^{*} A^{3} * \Gamma(1+3 / C)$

Where $A$ and $C$ are the parameters of the Weibull probability density function ( $p d f$ ) (JUSTUS $e t$ al., 1976):

The Weibull $p d f$ of wind speed ( $\mathrm{W}$ in $\mathrm{m} / \mathrm{s}$ ) is expressed as:

$P(W ; A, C)=(C / A)(W / A)^{C-1} \exp \left(-(W / A)^{C}\right)$

$A$ is a scaling parameter expressed in $\mathrm{m} / \mathrm{s}$, and $C$ is a dimensionless shape parameter.

$P$ indicates the probability of wind speed occurrence.

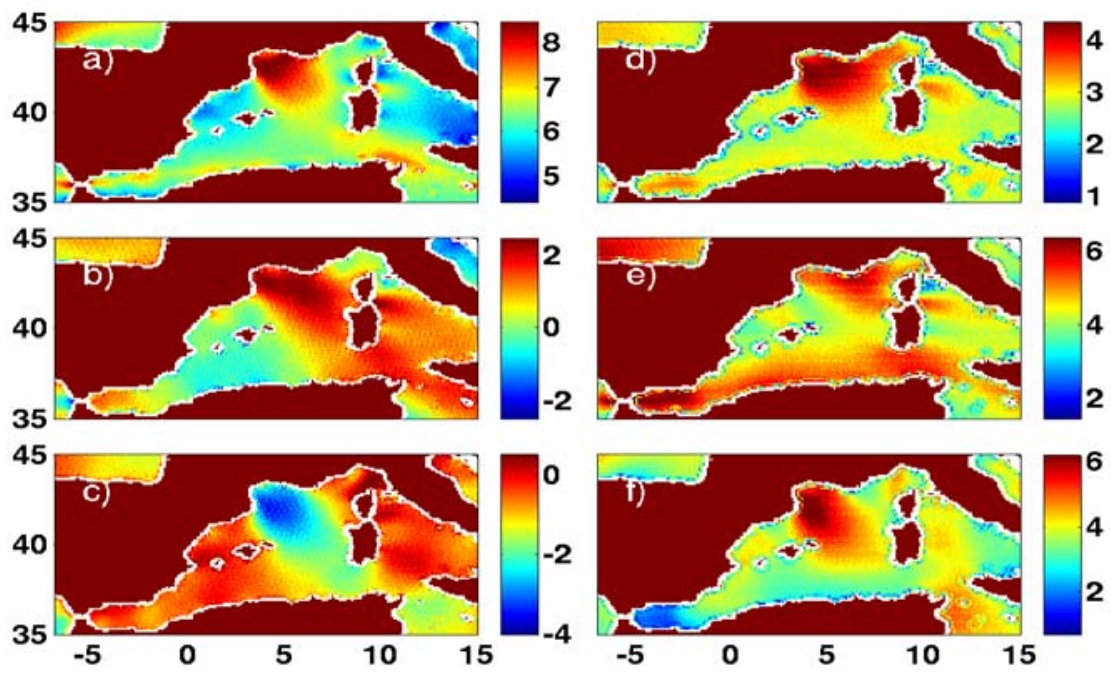

Figure 4. Spatial distribution of mean wind speed (a), zonal component (c), and meridional component (e). The associated standard deviation spatial distributions are shown in (b), (d), and (f). Statistics are calculated for 1992 through 2011.

As discussed by PAVIA \& O’BRIEN (1986) several methods exist to estimate Weibull parameters $A$ and $C$. However, they provide quite similar results. For instance the method of moment yields to the estimation of the mean $(\mu)$ and the variance $\left(\sigma^{2}\right)$ of Weibull distribution as a function of the Weibull parameters 
$\mu=A \Gamma(1 / C+1)$ and $\sigma^{2}=A^{2}\left(\Gamma(2 / C+1)-\Gamma^{2}(1 / C+1)\right)$

Where $\Gamma$ denotes the Gamma function. Using the above equations the Weibull parameters are determined as following:

$C=(\sigma / \mu)^{-1.086}$ and $A=\mu / \Gamma(1 / C+1)$
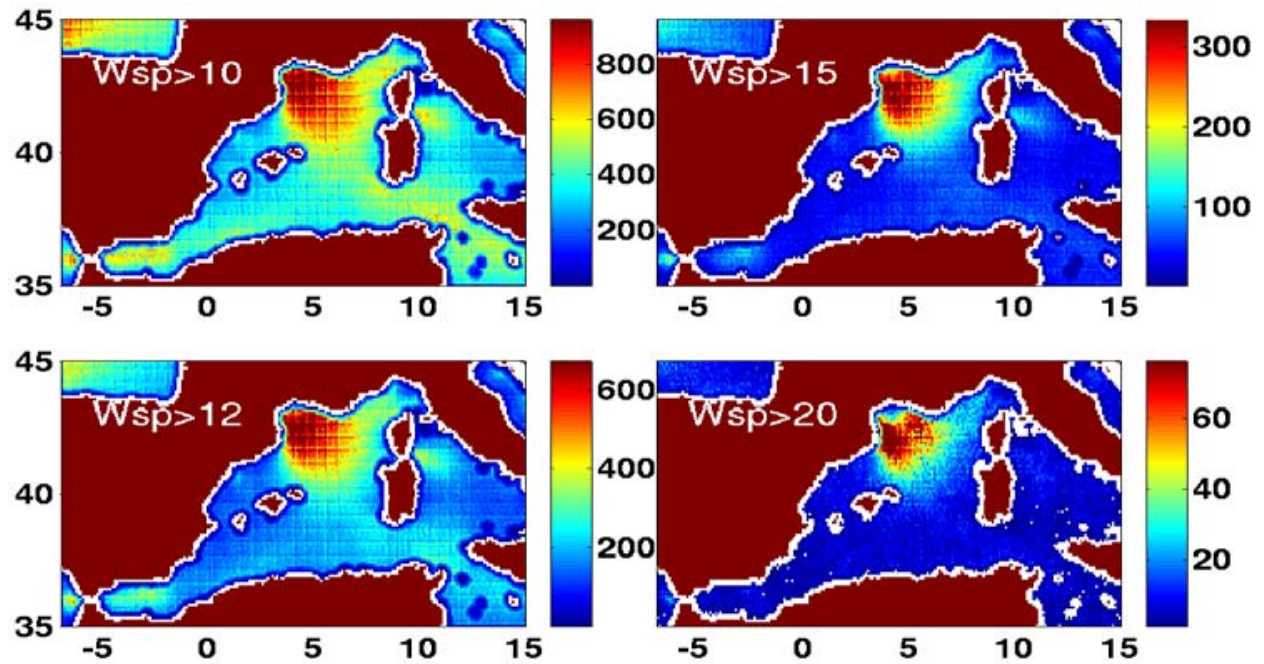

Figure 5. Spatial distribution of sampling length of wind speed (Wsp) exceeding $10 \mathrm{~m} / \mathrm{s}$,

$12 \mathrm{~m} / \mathrm{s}, 15 \mathrm{~m} / \mathrm{s}$, and $20 \mathrm{~m} / \mathrm{s}$. Statistics are calculated for 1992 through 2011 .

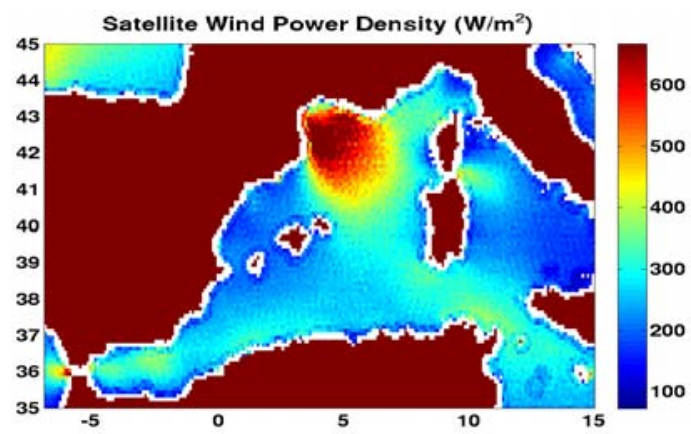

Figure 6. Spatial distribution of the wind power density estimated from satellite scatterometer winds occurring during the period 1992 - 2011.

Using all available scatterometer winds, the Weibull paramertrs $A$ and $C$ are calculated and thus the power density $E$ is estimated. Figure 6 shows an example of $E$ spatial distribution estimated for the period 1992-2011. As expected, it is quite similar to wind speed distribution (figure 4). The highest $E$ values are associated with high wind conditions found in the Gulf of Lion and cross Gibraltar strait. On average they exceed $600 \mathrm{~W} / \mathrm{m}^{2}$. Obviously and according to the results shown in the previous sections, power density distribution should have significant variability as a function of space and time. For instance, figure 7 shows significant seasonal variability of power density over south western region. 
La connaissance de la Mer :

un vecteur du développement durable en Méditerranée
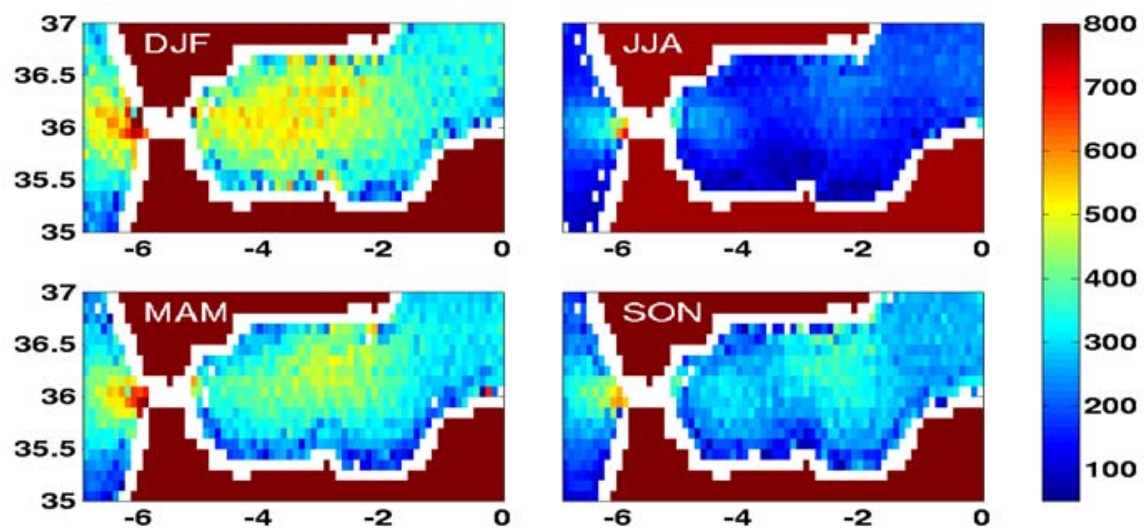

300

200

100

Figure 7. Winter (December January and February (DJF), spring (March, April, and May (MAM)), summer (June, July, and August (JJA)), and fall (September, October, and November (SON)) wind power density distributions.

\section{References}

BENTAMY A., KATSAROS K B., ALBERTO M., DRENNAN W. M., FORDE E.B. (2002). Daily surface wind fields produced by merged satellite data. American Geophys. Union, Geophysical Monograph Series Vol. 127, pp 343-349. doi:10.1029/GM127p0343

BENTAMY A., AYINA H.L., QUEFFEULOU P., CROIZE-FILLON S. ( 2007). Improved Near Real Time Surface Wind Resolution over The Mediterranean Sea. Ocean Sci., 3, pp 259-271. doi:10.5194/os-3-259-2007

BENTAMY A., KATSAROS K., QUEFFEULOU P. (2011). Satellite Air Sea Fluxes. In: Remote Sensing of the Changing Oceans, Edited by DanLingTang, Springer, pp 141-168. doi:10.1007/978-3-642-16541-2_8

BOURASSA M.A., LEGLER D.M., O’BRIEN J.J., SMITH S.R. (2003). SeaWinds validation with research vessels, J. Geophys Res., Vol 108, C2, 3019. doi:10.1029/2001JC001028

EBUCHI N., GRABER H.C., CARUSO M.J. (2002). Evaluation of wind vectors observed by QuikSCAT/SeaWinds using ocean buoy data. J. Atmos. Oceanic Technol., 19, 2049-2069. doi:10.1175/1520-0426(2002)019<2049:EOWVOB>2.0.CO;2

JUSTUS C.G., HARGRAVES W.R., YALCIN A. (1976). Nationwide assessment of potential output from windpowered generators. Journal of Applied Meteorology, Vol. 15, pp 673-678. doi:10.1175/1520-0450(1976)015<0673:NAOPOF>2.0.CO;2

PAVIA E.G., O'BRIEN J.J. (1986). Weibull statistics of wind speed over the ocean. J. Climate Appl. Meteor., 25, pp 1324-1332.

doi:10.1175/1520-0450(1986)025<1324:WSOWSO >2.0.CO;2 